\title{
The Importance of Public Participation in Sustainable Solid Waste Management
}

\author{
Lubna Salsabila ${ }^{1}$, Eko Priyo Purnomo ${ }^{2}$, Hazel D. Jovita ${ }^{3}$ \\ 1,2 Department of Government Affair and Administration, Jusuf Kalla School of Government, Universitas Muhammadiyah \\ Yogyakarta \\ ${ }^{3}$ Department of Political Sciences, Mindanao State University - Iligan Institute of Technology, The Philippines \\ Corresponding Author: Iubna.salsa@gmail.com \\ doi) https://doi.org/10.18196/jgpp.v8i2.11519
}

Article Info

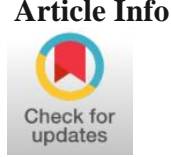

Article History;

Received:

2021-04-17

Revised:

2021-04-28

Accepted:

2021-06-14

\begin{abstract}
This study aims to do comparative analysis of what influence the SWM in Indonesia and the Philippines. As Sustainable Development Goals (SDGs) will not be achieved as long as the Solid Waste Management problem is left unsolved. Municipal Solid Waste Management (MSWM) has become a common issue in most developing country along with the rapid urbanization development and globalization. Qualitative approach chosen to analyze literatures selected related to SWM during 2000-2020. Data obtained from previous studies in this article were analyzed by the NVivo 12 Plus. The results shown that governance and participation become the main factors affected the status of MSWM as it is mentioned in most of the previous studies in the Philippines. Which is different with the previous studies in Indonesia.
\end{abstract}

Keyword: Local Governance; Public Participation; Municipal Solid Waste Management.

\section{INTRODUCTION}

Rapid urbanization has not only increased the quality of human life's but also in how the government playing its role in serving public needs. Sadly, a lot of people has forgotten that rapid urbanization, as part of the development has worked as a two-edged sword (Jung \& Moon, 2007). In which some scholars consider the program implemented in the name of the event will not be able to answer the problem yet resulting other problem (Jabbra \& Dwivedi, 2004; Zin, Lee, \& Rahman, 2002). Development can be seen from a series of aspects, such as political changes, economics, social, and country's demographic. In government aspect, it is believed that the development of the public sector institution can be affected and can be seen from the way in which the policies are implemented and from what is achieved or it can be said that the development of public sector institution have an infinity loop with the development policies qualities (Jung \& Moon, 2007; Turner \& Hulme, 1997).

Unfortunately, not every country able to pull off the negative side resulted from development. In 2018, Indonesia had an estimated population of 267.7 million, which was then predicted by the United Nations to be 273 million by 2020. With that number, Indonesia has become the country with the largest population in the rest of the ASEAN countries, followed by the Philippines with a population of 106.7 million in 2018 and an estimated 109.5 million in 2020 (United Nations, 2019). Followed with the high population density, both Indonesia and the Philippines face similar problems, such as limited land availability and waste generation.

Solid waste is containing multiple dangerous things and hazardous materials, such as chemical substance and diseases. The substance that carried out by debris will undoubtedly harm the environment and those people that work and live in the landfill area (Damanhuri \& Padmi, 2010). The CIA reported in The World Factbook that Indonesia and the Philippines are facing the same environmental problems associated with rapid urbanization and economic 
development, including air and water pollution in major urban centers and waste management. Which then make both of the countries joined to the Basel Convention Agreements (Central Intelligent Agency, 2018).

With high density and rapid movement of urbanization, both Indonesia and the Philippines are suffering to the similar problem of solid waste management. Land availability and untreated waste that polluted the water and soil become the major problems that both municipal need to overcome. With Republic Act 9003, the Philippine has made solid waste as part of municipal responsibility. The RA 9003 has clearly mentioned the importance of segregation and the prohibition of open dumping system. Which is still happening in several municipality, such Iligan City, and it is supposed to be considered as a violation to the law. In another side, lack of public participation and involvement in generating the program become other factors that make the implementation of solid waste management hard to achieved its maximum goals. Which has also happened in Yogyakarta City in Indonesia, since the implementation of Regulation No 18/2008 was not properly implemented due to the low level of public participation. People in Yogyakarta seem to have little knowledge of the policy itself that does not make them aware of the current state of waste.

SWM, need to be addressed as a priority or Sustainable Development Goals (SDGs will not be able to be achieved. The high amount of waste has become very frustrating nowadays and most of it are untreated. Hazardous material carried by solid was has been devastating and threatening human life, both for now and in the future. Unmanaged landfill, and open dumping system has polluted the water and the soil (SDG 15). Which sometimes also being carried out into the oceans. It is become a common issue in where waste can be found in the coastal area carried by the ocean and it is threatening life below water (SDG 14).

Unmanaged dumping system is also polluting the air and risking the people life around the dumping site. Dumping waste in open space and burn it has become the common method used in both Yogyakarta and the Philippines. Even though, certain regulation has been made, it seems that most of the people still done it in conventional and traditional way. The health impact of burning waste is become catastrophic and as one of the factors that in charge for the climate changes issues (SDG 3). Without proper treatment, open dump might turn into manmade greenhouse gases (SDG 13). Untreated waste and poorly managed open dumping system will also contaminate the water as it is contaminated the soil. The soil that contaminated with hazardous chemical will contaminated the water resources and sanitation (SDG 6).

The government inability has also made the people solely rely on local community rather than to government units. Which means that the public trust towards government has loss. Solid waste management has gain the attention from the global community (Castillo \& Otoma, 2013). Government has always put the landfill location outside of urban area and sometimes hard to be found by the people. The reason why the government took that action is because its' pose tremendous health hazards (Derakhshandeh \& Beydokhti, 2014). While in the same times it also making waste problem out of sight of people. Increasing the solid waste management quality standard will not enough (Molina-Motos, 2019), government need to be able to govern everyone to share the same burden of SWM (Wilson, 2007).

Government needs to re-think about the SWM by reflecting into five form of capital; (1) Human Capital; (2) Financial Capital; (3) Physical Capital; (4) Public Infrastructure Capital; and (5) Social Capital. Those five forms of capitals are believed can affect to improve the SWM. In adding a value to the human and social capital, financial capital will increase and affect the other forms. The value given are needed to change the perspective of the decision makers and start including the informal sectors as one of their interest. With certain value on informal sectors, government could consider the informal sector as an effective tool to share responsibility toward solid waste problem (Sembiring \& Nitivattananon, 2010).

A mixed method conducted by Fatimah et.al (2020) shows that Jakarta, Semarang, Yogyakarta, and Magelang waste production was mostly generating from households and traditional markets. The research shows that most of the collected waste is still not segregated since the lack of residents' knowledge in doing proper waste segregations. In the other side, the research shows that most of landfill in each city has overburdened due to uncontrolled waste 
dumped and the open dumping mechanism that is still become the main method used in handling the waste. They imply that even though Indonesia government has created a certain regulation regarding to solid waste management, most of local government in Indonesia still doing the traditional and conventional ways in handling waste. Poor management, lack of human resources, has made the current waste management system in Indonesia is still not able to identify the specific characteristic, amount and types of municipal waste collected in the final collection (Fatimah, Govindan, Murniningsih, \& Setiawan, 2020).

Lack of knowledge about the law by the government personnel, widespread as a common problem that can be found. This situation has resulted the condition in which most countries are not able to achieved its goals. In term of solid waste management, a proper policy will not be able to work without a proper action done by the government personnel and also its citizens. A research by Puspita et.al (2019) has shown how the collaboration between government with the community will resulting a better output. Proper monitoring system and well-managed mechanism of waste need to be existed as part of the policy implementation (Puspita, Kurnia, \& Yevendri, 2019). The previous study has shown how solid waste management should be considered and threated as one of governance problem. SWM is a critical component in establishing a sustainable urban development. Unmanaged SWM becomes a factor for dissemination of numerus ailments. The research in India conducted to analyze the current status and challenges faced by the municipalities due to the rapid urbanization and uncontrolled growth rate. There are five important examination of parameters done in this study in aims to understand SWM practice in India, such Segregation, Collection, Reuse/recycle, Transportation, and Disposal. In India, the segregation is not organized and planned well. The waste sorting mostly done by the informal or unorganized sectors practiced by waste producers. The segregation usually takes place in unhealthy and hazardous environment which not only harmful for those whom do the works but also no effectives due to improper sorting and disposal systems. Waste produced by the household usually transferred to communal bin in the neighborhood. This waste collection systems are not so effective remembering the possibility for the sorted waste got mixed up again in the communal bin (Joshi \& Ahmed, 2016).

Joshi and Ahmed (2016) elaborated that reuse/recycle activities in India municipals' involving activities such collecting material from the waste, which could be transformed and utilized for making new goods. However, this activity is rarely to be found in India, remembering most of the household waste is transferred to communal bin. Furthermore, transportation systems in India are also become another factor that makes the solid waste management in municipal could not be done effectively. The limited financial component makes the vehicle's maintenances hard to afford by the municipals, which makes the disposal efficiency decreased when the vehicles broken. Another reason is there is a limitation transfer station found in municipal and open dumping is the most common method used until nowadays in India. The study has also revealed that the using of this system has make the water sources and soil around the landfill areas polluted and contaminated with the hazardous chemical from the waste (Joshi \& Ahmed, 2016).

A proper management in each stages of solid waste management is very important. A good management in segregation will not be effective if the collection system is not coordinated well. Local government need to put a specific additional budget to differentiate transportation types (depends on the waste's categories). As SWM has always been a complicated problem that government in most countries struggle with. A lot of models and strategies made by the government in aim to reduce solid waste production but the problem is remaining to exist. Adopting other's country strategies seem to be not the right answer for any government to reach a sustainable solid waste management. In consideration to the fact that every government have different capability in handle solid waste problem, each government really need to create a certain policy that meet the needs of its' people.

In doing so, the government need to be able to analyze the people collective need. This is not an easy task, especially if the level of public participation is low. As the early development initiative implemented a top-down participatory approach by most of countries, participation became a common issue in the development project agenda (Buchy, Ross, \& Proctor, 2000; 
Claridge, 2004). this model has receiving a lot of critiques from many scholars both in its practice and theory. The condition in where the citizen will not be able to take part in the development project became the major reason why this model was criticized. This is very crucial matters since every policy made by the government will definitely affect people lives (Ako, 2017; Stein \& Harper, 2000).

Therefore, this paper will look and analyze the solid waste management in two cities in two different countries, Yogyakarta-Indonesia and Iligan-the Philippines. This study aims to analyze the trend and pattern of solid waste management in both countries. On the other hand, assessing whether social capital have significant influence towards the level of participation in the implementation of any waste programs in both Indonesia and the Philippines. Moreover, it can help both countries in understanding the maturity of solid waste management and giving an insight in how developing an effective and sustainable SWM. In line with these, by knowing the trends and the patterns of solid waste management will help both national and local government in maximizing their efforts in achieving the Sustainable Development Goals (SDGs).

\section{RESEARCH METHOD}

The objectives of this research are to look into the issues of Indonesia's and the Philippines' solid waste management systems in response to the externalities costs of development and urbanization. Through a literature review, a qualitative method was used to study the trends and patterns of SWM. In order to describe the solid waste management problem that exists in both countries, an exploratory qualitative study is conducted. According to Creswell (2014), this approach is used to seek new insights through the provision of questions and ideas for future research. It is a preliminary investigation to determine the precise nature of the problem to be resolved. In this study, the focus will be on how public participation affects the sustainability of solid waste management (Creswell, 2014).

By comparing the literature, the researcher uses deductive literature review techniques to determine the problem formulation and conceptual framework in this exploratory qualitative research method. The NVivo 12 Plus software was used to analyze references from previous studies in solid waste management with regard to public participation.

\section{RESULT AND DICUSSION The Philippines}

Waste generation in the Philippines continues to rise with population growth, improved living standards, rapid economic growth, and industrialization especially in urban areas. Under RA 9003, the local government units (LGUs) are responsible for collecting, transporting and disposing of solid wastes. Most LGUs currently administer their own collection systems or contract to private contractors for this service. The NSWMC, supported by the Environment Management Bureau (EMB), is currently fast-tracking the approval of all LGUs that have submitted their 10-year SWM plans to ensure the proper implementation of SWM systems. As of 1 September 2017, the NSWMC Secretariat had received around 460 SWM plans (Senate Economic Planning Office, 2017).

The Republic Act (RA) No. 9003, widely known as the Ecological Solid Waste Management Act of 2000, provides the required policy framework, institutional mechanisms and mandate to the Local Government Units (LGUs) to achieve 25\% waste reduction target through establishing an integrated solid waste management plan based on the 3Rs (reduce, reuse and recycling). Although the significant impact is still very limited to be found in the implementation of national mandate by the LGU, several cities able to reach $30 \%$ of the target (Premakumara, Canete, Nagaishi, \& Kurniawan, 2014). 


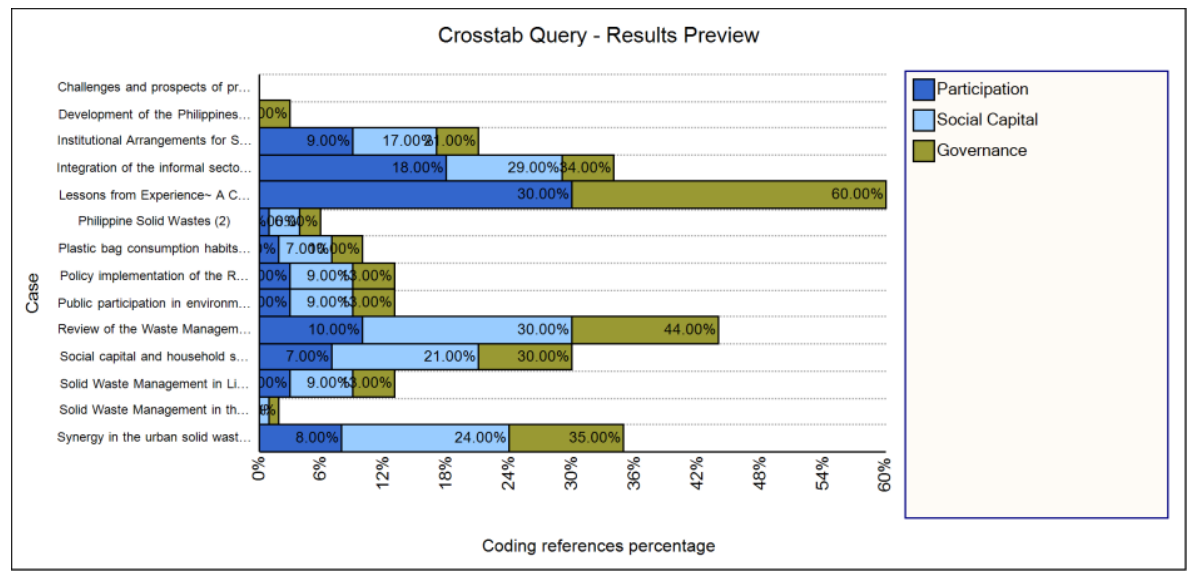

Figure 1. Crosstab Query - Literature of SWM in the Philippines

A crosstab query done using NVivo 12 Plus to analyze the common focus from 14 journals related to Solid Waste Management in the Philippines from $2004-2020$. The result shows that most journals focused on the governance aspect.

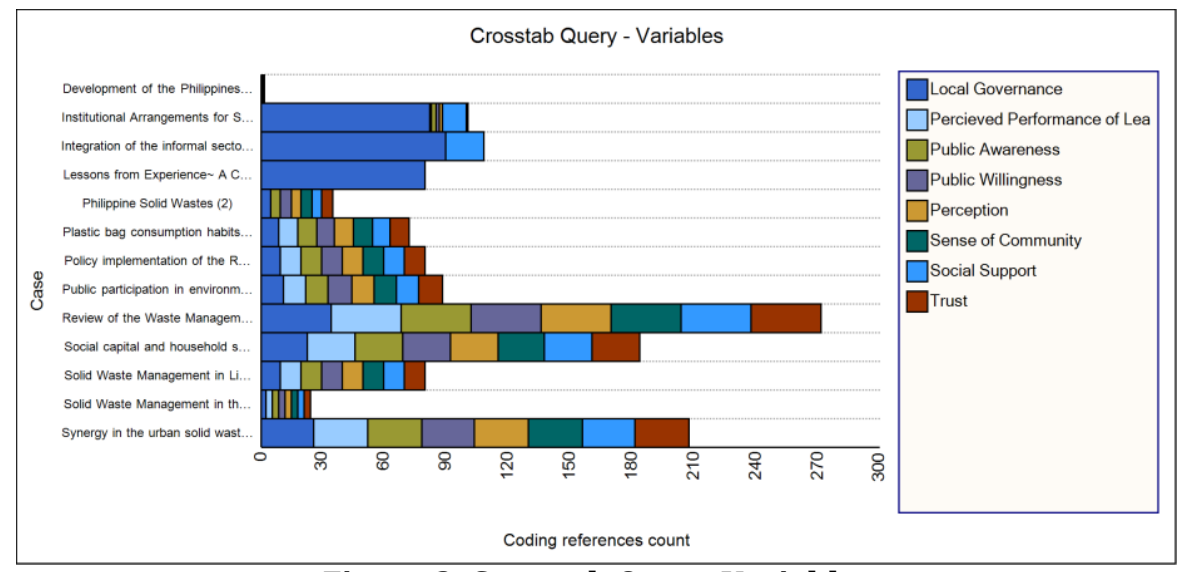

Figure 2. Crosstab Query Variables

On 2017, a documentation of how solid waste management handled in Iligan released on April 2017 show a contradicted evidence of solid waste management in Iligan City. A video titled "Reporter's Notebook: Bundok ng basura sa Iligan City, may dalang peligro sa mamamayan" or in English translated as "Reporter's Notebook: Mountains of garbage in Iligan City, bringing risk to the people" released in the official GMA Public Affairs YouTube channel. An analysis done by coding the sentiment from the documentary transcription in Nvivo. The result shows that the documentary contains with 46.75 percent of negative sentiment. The 26.96 percent of negative sentiment coming from the statement given by the scavenger and the resident whom lives around the landfill areas. While the 19.79 per cent comes from a statement made by local officials that the fragmented state of the current political situation has made any solution does not mean anything (NVivo, 2020).

The documentary has somehow showed how the local government in Iligan City has failed in maximizing the facility provided in the landfill. The statement given by the local officials whom claimed that they had tried their best to make sure the facility operates well by calling fixers to fix the broken machine is vague due to the fact that the machine broken even more. Maintaining has always been a common problem that most of developed country need to face when technology came as the solutions (Hajduk, 2016). 


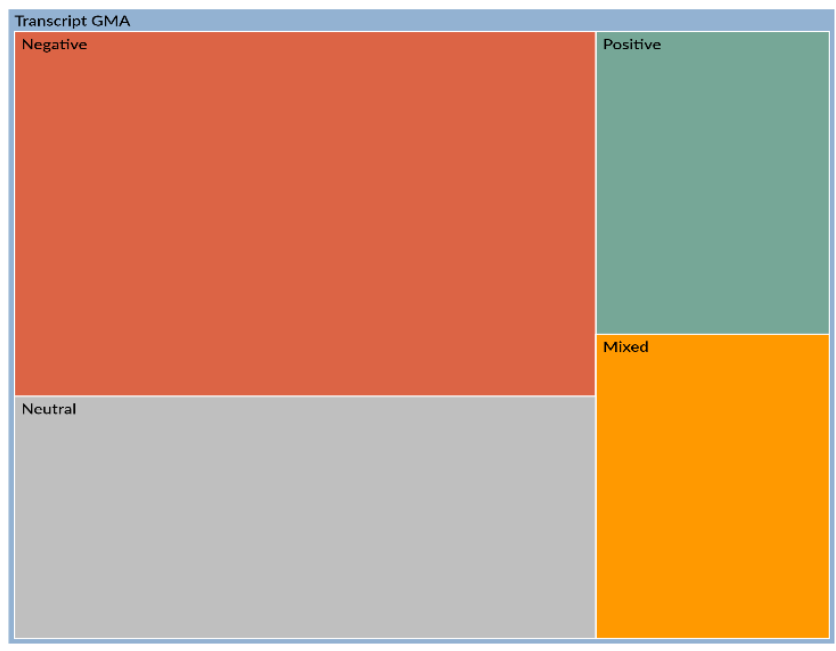

Figure 3. GMA Public Affairs Reporter's Notebook Sentiment Source: NVivo (2020)

The report is very contradicted with the previous City Mayor Report on 2012. In his report, he declared that most of the program or project implemented in aims to reduce and managed solid waste has been 100 percent accomplished (see Table 1.1). An institutional program was also made between the Iligan City Solid Waste Management (ISCWM) - Project Management office with The Barangays Solid Waste Management Committees in aims to strengthen the Iligan City Solid Waste Management (ICSWM, 2012).

During 2012, Iligan City Mayor perform well-enough considering that most of his program components reports in solving solid waste management problem are 100 percent completed. Therefore, after five years thus report being released, the condition in Iligan landfill shows different result. Based on the documentary, the limitation of space become the major problem that makes the local government initiated to open a new landfill without the council permit. Facilities, such separation machine and dumping pit does not work as it supposed to be. The machine has been stop operating after the first usage and the dumping pit has not even been use since it was made (GMA Public Affairs, 2017).

Solid waste management remains a major challenge, particularly in urban areas, in the Philippines. Improper disposal of waste, inefficient collection of waste and lack of disposal facilities are among the main concerns in the country's solid waste management. The Republic Act No. 9003, better known as the 2000 "Ecological Solid Waste Management Act," enacted on January 26, 2001, aims to tackle the country 's rising issue of solid wastes (the Republic of the Philippines, 2001). It provides a legal framework for a systematic, comprehensive and ecological waste management program in the country to ensure the protection of public health and the environment. It also provides for the required institutional frameworks with the establishment of the National Solid Waste Management Commission (NSWMC), which will oversee the implementation of solid waste management plans and recommend strategies and incentives for achieving the Act 's objectives.

Waste generation in the Philippines continues to rise with population growth, improved living standards, rapid economic growth, and industrialization especially in urban areas. Under RA 9003, the local government units (LGUs) are responsible for collecting, transporting and disposing of solid wastes. Most LGUs currently administer their own collection systems or contract to private contractors for this service. The NSWMC, supported by the Environment Management Bureau (EMB), is currently fast-tracking the approval of all LGUs that have submitted their 10-year SWM plans to ensure the proper implementation of SWM systems. As of 1 September 2017, the NSWMC Secretariat had received around 460 SWM plans (Senate Economic Planning Office, 2017).

A research of public participation in enviromental governance and its challenge in consolidating with the state by Gera (2010) found that the participation proces is significantly in 
the low level while the country appears to has a strong institutional setup for the public due to the substantial autonomy from power structures that could not be achieved. She also argue that the weakness in public deliberations among civil society groups amid complexity in aggregating plural interest of representation, coherence and consolidation in egagement with government institutions. Also, the lack of institutional mechanism has weakening the mutual learning and concensus in the country. Which then led to the lack of recognition of mandates. The scholar imphasizes that relationship among sectors become the key point in determining the future of enviromental governance in the Philippines (Gera, 2016).

Paragoso et. al (2018), in his works, reveal that most of the correspondent does not understand the term of natural environment. A lack of understanding about waste disposal method makes the implementation of RA 9003 hard to achieved. From 313 respondent, about 47 percent burn down the trimming yard and burn the paper waste based. While for the metal waste, the study shows that most of the respondent disposed it to the itinerary buyer and leave the plastic waste to the garbage truck. The study also reveals that eight (8) barangay respondents were highly concerned about the health risks associated with garbage burning, illegal dumping of contaminating streams and rivers, sicknesses due to improper storage and disposal methods, garbage swamping, litter and illegal dumping in the neighborhood. The study shows that the majority of respondents were concerned only with services provided by the government's garbage trucks (Paragoso et al., 2018).

Tinio, Rollon, and Moya (2019), in their works found that there is significant relationship between public participation with waste diversion in Malolos City. The study has revealed that the involvement of public participation in solid waste management program has able to reduce the numbers of waste in 2018. Therefore, the other aspect such decent program facilities, such recycling and composting sites has also affecting public willingness to participate in the program. They argued that the involvement of public participation has provide bigger opportunities for the informal sector to be part of the program and the inforcement of public involvement have improved the outcome of recycling program. They also implies that government budget as a form of government support also help the program to be spread widely in the community (Tinio, Rollon, \& Moya, 2019).

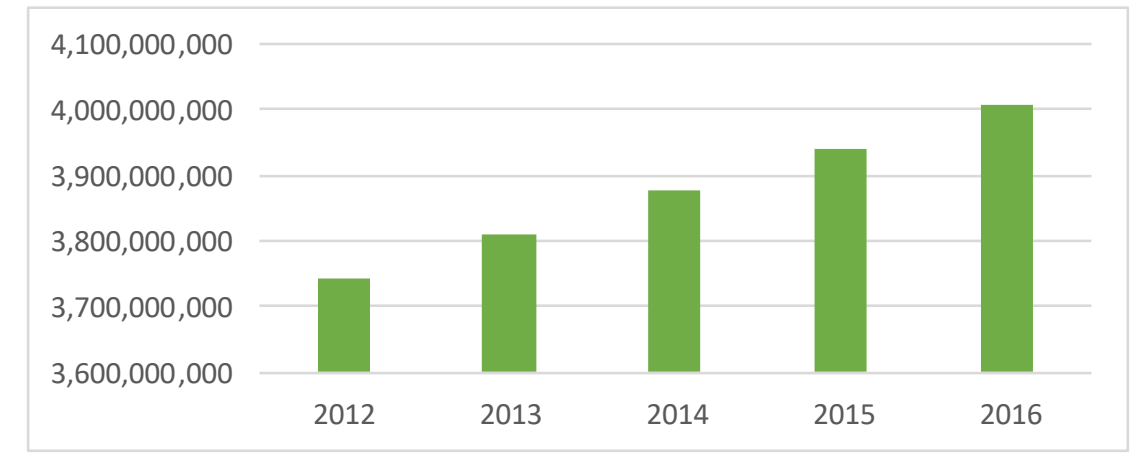

Figure 4. The Philippines' Waste Generation 2012-2016 (in $\mathrm{m}^{3}$ per day) Source: NSWMC

A descriptive research done at three (3) municipals in the Northern Philippines in 2020, shows as a respondent's age drops, his / her weekly consumption of plastic bags increases. Whether respondents reside in Sarrat or Solsona has also been predicting consumption of weekly plastic bags. Sarrat respondents consume fewer plastic bags per week than Solsona respondents do. Similarly, whether respondents are residing in the plastic bag consumption forecast weekly in Vintar or Solsona. Yet, the research shows the education level has nothing to do with the number of solid waste-plastic-produced (Crowley, 2020).

Further, the majority of the respondents' in Linamon Municipals concurred that having a recycling laws and program in the first place is very important. In the other hand the Magoong barangay study resulting that the majority of the respondent thinks that environmental 
education should be taught in the school. This illustrates the awareness of the importance of basic education for young generations in relation to solid waste and the importance of environmental protection. Regarding to the study, the most of respondents are highly willing to participate in solid waste management (Paragoso et al., 2018).

The previous studies about public participation and solid waste management in Philippines has interstingly shows how public knowledge about the issues has a significant relations ro the mandates recognition. Studies has also shows the significant impact given by the involvement of public participation in reducing the volume of waste in the Philippines. Government support in the same time play another important role, which is in this case is as a fuse for the public to decide wheter they willing or not to be participated in the program.

\section{Indonesia}

For several few years, the environmental degradation has slowly getting more attention from the government and public. A lot of efforts have been taken by the government of Indonesia and the Philippines in aims to tackle the issues occurs in the community such as flooding and clean water supply. By enacting Regulation No. 18 year 2008 about Waste Management, Indonesia government acknowledge the dangerous effects caused by the waste to the environment and human lives. Under the regulation, Indonesia government acknowledge that waste has become their responsibility since the citizens has their right to enjoy a good quality and healthy lives. In which to make this happen the government emphasize that every action taken should consider the sustainability matters.

However, Regulation No 18/2008 appears not to have been well implemented even 12 years after it was signed. Under this regulation, Indonesia government tries to change the open dumping paradigm to reuse, reduce, and recycling (3R) (Indrawati, Sunaryo, Budi Raharjo, Clara Shinta, \& Budi Khoirani, 2018). Most of the local governments in Indonesia are only collecting, transporting and then dumping the garbage to the landfill without taking into account the selection, separation, transport and management aspects of the landfill. This action then has made the land availability meets its crisis in Piyungan Landfill, Yogyakarta.

In 2019, Indonesia has produced about 66-70 million meters tons (MMT) of waste. Reduction of solid waste has always been one of the problems that Indonesia face due to the rapid urbanization grows. Under the Regulation No. 18 year 2008 about waste management, Indonesian government acknowledged the negative impact made by waste since it might harm human lives. The regulation clearly mention that waste management is part of the local government responsibility under the provision of national government. Yet, not every municipalities able to achieve the policy goals. Waste management is not easy, but it is very complex, because it covers technical, economic and socio-political aspects. Waste management is an effort to manage or manage waste from collection, collection, transfer, transport, processing to final disposal.

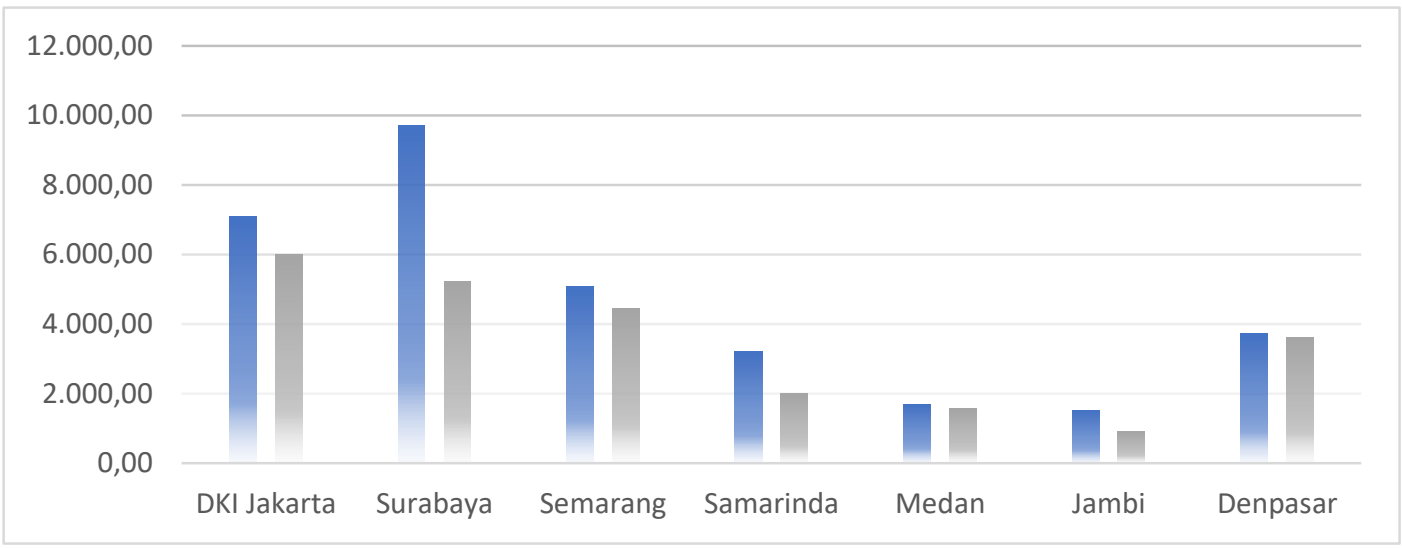

Figure 5. Production and Volume of Waste Transported Per Day in Several Capitals in Indonesia $2016\left(\right.$ in $\mathrm{m}^{3}$ )

Source: Central Bureau of Statistics (2016) 
Lack of integration between the Public-Private-Community has always been one of the major factors influence the poor solid waste management system in Indonesia (Yogiswatin, 2014). A mixed method research done by Wahyudi et.al (2012) to analyze the solid waste problem in Malang City, Indonesia. The research was focused in understanding the strategic plan taken by the Department of Environment in local level. Authors were analyzing the effectivity of the National Policy used as the fundamental source in managing solid waste management. The output and outcomes of the implementation were measured by comparing the operational technique with social and financial capital (Wahyudi, Abdillah, \& Nutqhi, 2012).

Limited government fund and not enough space for the government entities make the solid waste problem became a difficult task to achieve. As the research found that the output and outcomes produced from the operational technique taken was not able to cover the social and financial capital. It is because the Malang City is still using the old paradigm in managing solid waste management-gather, transfer, and dump-which is also not in line with the National Policy requirements (Wahyudi et al., 2012). Which is also happened in several capital in Indonesia. Yet, the Regulation No. 8 year 2008, clearly mention that there is a need of change in the operational techniques in managing the solid waste management by focusing in reducing and controlling the waste. In doing so, either government, private or business sectors, and citizen able to involve and participate in reducing and controlling solid waste by conducting recycle and others form of activities which are innovative, efficient, and sustainable (Republik Indonesia, 2008).

In the other hand, a research revealed the Malang city government was failed in engaging with the public. By measuring the people responsibility, willingness and awareness, authors found that the people's perspective through waste become the key point. The results of the study showed that most people felt that they had fulfilled their obligations by paying sanitation fees to the waste workers, so they felt that they no longer needed to be involved in waste disposal management. The limited knowledge of the community on how to manage waste efficiently and the risk of waste itself has also shown that the government has not been able to engage the public in participating. Resistance from the public happen due to the lack of public participation at the planning stage (Wahyudi et al., 2012).

Further, a research by Syam (2014) shows the significant result about the relation between the public knowledge with the public participation level in SWM implementation in Donggala District. An interview conducted with 96 people, resulting a $p$ value $=0.00(\mathrm{p}<0.05)$ indicating that lack of knowledge about waste management influencing the level of public participation which also causing the ignorant attitude from the people. The author imply that the lack of knowledge in Donggala District caused by inadequate transfer of knowledge from government to the people (Syam, 2014).

Most of the municipals in Indonesia has started a new way in managing SWM. By involving the Non-Government Organization and other private or business sectors, most of the local government in Indonesia implementing the Bank Sampah or Waste Bank system as a form of 3R program (Reflay, Hayu, \& Djumiarti, 2013). A mixed method research conducted by Putra et.al in Yogyakarta on 2019 discussed about the importance of government collaboration in managing solid waste. Yogyakarta, as one of the provinces in Indonesia established around 117 independence waste management groups called as Lestari in 2011 and became 155 groups in 2015. The groups it-self consisted by the local scavenger around the landfill area. The Lestari program runs under the Ministry of Environment Regulation No 13/2012. Lestari basically is a Community-Based organization which consist of at least 800 household spread all around Yogyakarta and most of it are the scavengers who lives around the landfill area. The research shows that on 2015, this groups has successfully reduced $70 \%$ of waste in segregation areas. At this point, it seems that the government were able to collaborate well with the community and the private sectors (Putra, Damanhuri, \& Sembiring, 2019).

Research on the development of waste management practices in Indonesia by Meidiana and Gamse (2010) found that existing regulations on waste management (Regulation No. 18/2018) has not been well implemented in Indonesia. Through 'the end-pipe-approach', the analysis shows that one of the major problem that most cities in Indonesia struggle with is the 
limited land availability and over burderned landfill. Which then worsen since the open dumping sites operates with no sanitary system. They also added that low waste regulation enforcement in local level, inadaquate level of services, low community awareness, and low participarion become another obstacles that makes the SWM in Indonesia performance remains low (Meidiana \& Gamse, 2010). These findings explained about what currently happened in Yogyakarta for the past few year. Piyungan landfill in Yogyakarta has been forced to shut by the people whom stay around the landfill. Poor management and systems has caused the landfill has not enough space for the open dumping waste operation, which also causing land-slide during rainy season (Syambudi, 2019). This research has also implies that even after almost ten years gap to the current event, there is still no significant changes in the implementation of solid waste management in Indonesia.

Raharjo et.al (2015), in their research on community-based solid waste bank porgram for municipal solid waste management improvement in Padang City, shows that even though solid waste bank program considered as the best community-based program in supporting both National (Regulation No.18/2018) and Local (Local Regulation No. 51/2012) regulations in Indonesia, the program is still lacking of government support. The study shows that the program only received a small amount of support from the government officials. The support mentioned by the researchers in this context is in a form of information sharing and coordination. The SWOT analysis shows that the representative at the municipal levels work without any proper coordination and there was no technical planning used in the operation. They also mentioned that the operations of SWM done by the local government unit were obeying the principle of recycling such proper segregation and decent transportation systems. This condition has resulting a decreasement of community willingness to be part of the program. Low personal commitment of officials has also made the communities consider the program less important that it is supposed to (Raharjo, Matsumoto, Ihsan, \& Rachman, 2015).

A Crosstab and Chi Square Analysis done by Maryati et.al (2018) shows about 64 percent of 170 individuals have no knowledge about waste bank program in Malang City. This is very interesting finding, considering the fact that the waste bank program was launched on 2011 in Malang City. The study has also found that the other 46 percent have a decent knowledge about the program from the information given by some organization campaign. Most of those who are interested to joined the program were invited by their family, friends, and neighbors. They also mentioned that those three actors are the main factor that influence household participation in solid waste bank management program. Therefore, a lack of local government support, especially in promoting the program and providing an accessible informations becomes the major obstacles that need to be prioritized by the government (Maryati, Arifiani, Humaira, \& Putri, 2018).

Additionally, Pandebesie et.al (2019), in their work found that behavior, attitudes, and knowledge were the most important factors that influenced community participation of solid waste in West Surabaya. Survey conducted has revealed that a person knowledge significantly influence public willingness to participate in the program. They then added that severals kind of campaign from the local government need to be done. Local government need to work as the provider of the program by providing enough information resources and equipment. They also implies that the gigh levels of participation will help the government to construct a better formulation of regulations. By doing so, scholars argued that it will also encourage people to manage their own household waste (Pandebesie, Indrihastuti, Wilujeng, \& Warmadewanthi, 2019).

The previous studies about solid waste management in Indonesia shows several similarities, which is most of scholars argues that people knowledge (awareness) and willingness will indicates their participation or involvement in the program. The studies also shows that the lack of knowledge of the programs was caused by the lack of local government support in promoting the programs. The fact that there is still no proper 'transfer of knowledge' in the program implementation shows the lack of government support in promoting the community-based program. It also indicated that the relationship between those two sectors is 
not good enough during the implementation. Additionally, family, community, and neighbors are playing a significant role as the catalyst in the terms of information distribution.

Literature studies presented were selected based on the abstract, keywords, findings, and its focused. Around 43 journals were selected related to the social capital, participation, and solid waste management and analyzed using NVivo. The result shows that around 1999-2020, most research were conducted around 2012 to 2017 and mostly taken places in Asia. The analysis also shows, only few studies have discussed about the development of solid waste management (Acosta, Paul, Lao, Aguinaldo, \& Valdez, 2012; Ako, 2017; Basu \& Punjabi, 2019; Dhokhikah \& Trihadiningrum, 2012; Fatimah et al., 2020; Permana, Towolioe, Aziz, \& Ho, 2015), especially in describing the relationship between social capital and participation (Gera, 2016; Jones, Halvadakis, \& Sophoulis, n.d.; Lindström, Merlo, \& Östergren, 2002; Maryati et al., 2018; Pargal, Huq, \& Gilligan, 1999; Raharjo et al., 2015; Tinio et al., 2019; Tsai, 2008; Wahab, 2015; Zarate, Slotnick, \& Ramos, 2008), and in how they might affect the current status of Solid Waste Management in a country (Azam \& Mansoor, 2006; Basu \& Punjabi, 2019; Dhokhikah \& Trihadiningrum, 2012; Perlaviciute \& Squintani, 2020; Permana et al., 2015; Syam, 2014; Zhang et al., 2019).

\section{CONCLUSION}

This review shows the trend and the pattern of solid waste management in both countries. Public participation in the implementation of waste programs in the Philippines shows a significant result compared to Indonesia's cases. The Philippines government shows much effort in involving public participation in the Philippines compared to Indonesia. The different approach in the program implementation has somehow make MSWM in the Philippine work much better in matter of waste reducing. Yet, in Indonesia, the government show more interest in policy and regulation part. As most of it are unclear and might lead into mistreated or disintegrated program implementation. Which then can also be seen that the maturity of the countries in handling solid waste management and giving an insight in how developing an effective and sustainable SWM are different in certain aspects.

\section{ACKNOWLEDGEMENT}

Our deep appreciation goes to Mindanao State University-Iligan Institute of Technology, which has helped us by providing a rich literature for this research.

\section{REFERENCE}

Acosta, V., Paul, J., Lao, C., Aguinaldo, E., \& Valdez, M. D. C. (2012). Development of the Philippines National Solid Waste Management Strategy 2012-2016. Procedia Environmental Sciences, 16, 9-16. https://doi.org/10.1016/i.proenv.2012.10.003

Aguja, H. J. (2016). The Line of Fit towards ASEAN Connectivity: Focus on the Philippine Political Structure and Processes. https://doi.org/10.18196/jgp.2016.0038

Ako, J. N. (2017). Participatory Development: A study of community and citizen participation in development and policymaking in Stockholm, Värmdo and Bortkyrka municipalities in Sweden.

Ancog, R. (2016). Institutional Arrangements for Solid Waste Management in Cebu City, Philippines. (January 2012).

Asefi, H., Shahparvari, S., \& Chhetri, P. (2019). Integrated Municipal Solid Waste Management under uncertainty: A tri-echelon city logistics and transportation context. Sustainable Cities and Society, 50. https://doi.org/10.1016/j.scs.2019.101606 
Azam, S., \& Mansoor, S. (2006). People as partners : Facilitating people 's participation in public - private partnerships for solid waste management. 30, 781-796. https://doi.org/10.1016/j.habitatint.2005.09.004

Basu, A. M., \& Punjabi, S. (2019). Participation in solid waste management: Lessons from the Advanced Locality Management ( ALM ) programme of Mumbai. Journal of Urban Management, (October), 1-11. https://doi.org/10.1016/j.jum.2019.11.002

Bing, X., Bloemhof, J. M., Ramos, T. R. P., Barbosa-Povoa, A. P., Wong, C. Y., \& van der Vorst, J. G. A. J. (2016). Research challenges in municipal solid waste logistics management. Waste Management, 48, 584-592. https://doi.org/10.1016/j.wasman.2015.11.025

Blair, H. (2000). Participation and Accountability at the Periphery: Democratic Local Governance in Six Countries. World Development, 28(1), 21-39. https://doi.org/10.1016/S0305-750X(99)00109-6

Bryson, J. M., Quick, K. S., \& Crosby, B. C. (2012). Designing Public Participation Processes: Theory to Practice. 73, 23-34. https://doi.org/10.111/j.15406210.2012.02678.x.Designing

Buchy, M., Ross, H., \& Proctor, W. (2000). Enhancing the information base on participatory approaches in Australian natural resource management. Land and Water Australia (Ed.) Natural Resources Management-People and Policy, Land and Water Australia, Canberra, 1-78.

Castillo, A., \& Otoma, S. (2013). Solid Waste Management in the Philippines. Japan Society of Material Cycles and Waste Management, (6), 19-20.

Central Intelligent Agency. (2018). Philippines vs. Indonesia - Country Comparison. Retrieved August 13, 2020, from https://www.indexmundi.com/factbook/compare/philippines.indonesia

Chanhthamixay, B., Vassanadumrongdee, S., \& Kittipongvises, S. (2017). Assessing the Sustainability Level of Municipal Solid Waste Management in Bangkok, Thailand by Wasteaware Benchmarking Indicators. Applied Environmental Research, 49-61. https://doi.org/10.35762/aer.2017.39.3.6

Claridge, T. (2004). Designing Social Capital Sensitive Participation.

Cooper, C. A., \& Nownes, A. J. (2003). Citizen Groups in Big City Politics. State and Local Government Review, 35(2), 102-111. https://doi.org/10.1177/0160323X030350020

Crawley, H. (2009). Understanding and Changing Public Attitudes. (June).

Crowley, J. (2020). Plastic bag consumption habits in the Northern Philippines. Resources, $\begin{array}{llll}\text { Conservation } \quad \text { and } & \text { Recycling, } & 104848 .\end{array}$ https://doi.org/10.1016/j.resconrec.2020.104848

Damanhuri, E., \& Padmi, T. (2010). Diktat Kuliah TL-3104 (1st ed.). Bandung: Institut Teknologi Bandung.

Das, A. (2015). Participatory Slum Upgrading: Lessons from Post-Decentralization India and Indonesia. Journal of Indonesian Regional Development and Environment, 2015, 1(1), 1534. https://doi.org/iirde.i-4.or.id/paper-download/IIRDE-Vol-1-15-34.pdf 
Dawes, S. S. (2017). The Evolution and Continuing Challenges of E-Governance Author ( s ): Sharon S . Dawes Commission Report Revisited: 21st Century Challenges Confronting State and Local Governance and How Performance Can Be Improved ( Dec ., 2008 ), pp . S86-S102 Publishe. 68.

Derakhshandeh, M., \& Beydokhti, T. T. (2014). Management of Landfill Locating of Urban Waste. 3(3), 32-39.

Dhokhikah, Y., \& Trihadiningrum, Y. (2012). Solid Waste Management in Asian Developing Countries: Challenges and Opportunities. J. Appl. Environ. Biol. Sci, 2(7), 329-335. Retrieved from https://www.researchgate.net/publication/284942823

Dhokhikah, Y., Trihadiningrum, Y., \& Sunaryo, S. (2015). Community participation in household solid waste reduction in Surabaya, Indonesia. Resources, Conservation and Recycling, 102, 153-162. https://doi.org/10.1016/j.resconrec.2015.06.013

Eardley, T. (2000). Australian Atiltudes To Unemployment And Unemployed P !: OPLE. 10, 181202.

Fatimah, Y. A., Govindan, K., Murniningsih, R., \& Setiawan, A. (2020). Industry 4.0 based sustainable circular economy approach for smart waste management system to achieve sustainable development goals: A case study of Indonesia. Journal of Cleaner Production, 269, 122263. https://doi.org/10.1016/i.jclepro.2020.122263

Fitzgerald, J. (2013). from Citizen Participation : Can We Measure Its Effectiveness ? 38(5), 457463.

Food and Agriculture Organization of the United Nations. (1997). State of the world's forests, 1997. Retrieved from http://www.fao.org/3/w4345e/w4345e00.htm\#Contents

Francis, P., \& James, R. (2003). Balancing Rural Poverty Reduction and Citizen Participation: The Contradictions of Uganda's Decentralization Program. World Development, 31(2), 325337. https://doi.org/10.1016/S0305-750X(02)00190-0

Gera, W. (2016). Public participation in environmental governance in the Philippines: The challenge of consolidation in engaging the state. Land Use Policy, 52, 501-510. https://doi.org/10.1016/j.landusepol.2014.02.021

GMA Public Affairs. (2017). Reporter's Notebook: Bundok ng basura sa Iligan City, may dalang peligro sa mamamayan. Philippines: GMA.

Grashuis, J., \& Ye, S. U. (2019). A Review of the Empirical Literature on Farmer Cooperatives: Performance, Ownership and Governance, Finance, and Member Attitude. Annals of Public and Cooperative Economics, 90(1), 77-102. https://doi.org/10.1111/apce.12205

Hajduk, S. (2016). the Concept of a Smart City in Urban Management. Business, Management and Education, 14(1), 34-49. https://doi.org/10.3846/bme.2016.319

Houtman, D. (1997). Welfare State, Unemployment, and Social Justice: Judgments on the Rights and Obligations of the Unemployed. Social Justice Research, 10(3), 267-288. https://doi.org/10.1007/BF02683304

Hwang, Y. (2011). Comparative Analysis of Indonesian and Korean Governance. LSE- Korea Doundation Academic Exchange Fellow - Asia Research Centre, 37, 1-28.

118 | Lubna Salsabila1 ${ }^{1}$ Eko Priyo Purnomo ${ }^{2}$, Hazel D. Jovita ${ }^{3}$. 
ICSWM. (2012). Status report. (December), 1-22.

Indrawati, S., Sunaryo, Budi Raharjo, A., Clara Shinta, R., \& Budi Khoirani, A. (2018). Reliability Centered Maintenance on Critical Component in Indonesian Commercial Trains. 2018 4th International Conference on Science and Technology (ICST). https://doi.org/10.1109/icstc.2018.8528632

Jabbra, J. G., \& Dwivedi, O. P. (2004). Globalization, governance, and administrative culture. International Journal of Public Administration, 27(13-14), 1101-1127. https://doi.org/10.1081/PAD-200039891

Jones, N., Halvadakis, C. P., \& Sophoulis, C. M. (n.d.). Social capital and household solid waste management policies: a case study in. (December 2014), 37-41. https://doi.org/10.1080/09644016.2011.551032

Joshi, R., \& Ahmed, S. (2016). Status and challenges of municipal solid waste management in India: A review. Cogent Environmental Science, 2(1). https://doi.org/10.1080/23311843.2016.1139434

Jung, K., \& Moon, M. J. (2007). The Double-Edged Sword of Public-Resource Dependence: The Impact of Public Resources on Autonomy and Legitimacy in Korean Cultural Nonprofit Organizations. Policy Studies Journal, 35(2), 205-226. https://doi.org/10.1111/j.1541$\underline{0072.2007 .00216 . x}$

Keesstra, S. D., Bouma, J., Wallinga, J., Tittonell, P., Smith, P., Cerdà, A., ... Fresco, L. O. (2016). The Significance of Soils and Soil Science Towards Realization of the United Nations Sustainable Development Goals. (i), 111-128. https://doi.org/10.5194/soil-2-111-2016

Keohane, R. O., \& Nye, J. S. (2017). Globalization: What's New? What's Not? (And So What?). 118(118), 104-119.

Lansbury, R. D. (1978). The Return to Arbitration: Recent Trends in Dispute Settlement and Wages Policy in Australia. International Labour Review, 117. Retrieved from https://heinonline.org/HOL/Page?handle=hein.journals/intlr117\&id=625\&div=\&collecti on $=$

Lindström, M., Merlo, J., \& Östergren, P.-O. (2002). Individual and neighbourhood determinants of social participation and social capital: a multilevel analysis of the city of Malmö, Sweden. Social Science \& Medicine, 54(12), 1779-1791.

Luo, X. (1998). What Affects Attitudes Towards Government' S Role In Solving Unemployment? A Comparative Study Of Great. International Journal of Public Opinion Research, 10(2).

Maryati, S., Arifiani, N. ., Humaira, A. N. ., \& Putri, H. . (2018). Factors influencing household participation in solid waste management (Case study : Waste Bank Malang). 0-5.

Meidiana, C., \& Gamse, T. (2010). Development of Waste Management Practices in Indonesia. $40(2), 199-210$.

Meredith, T., \& MacDonald, M. (2017). Community-supported slum-upgrading: Innovations from Kibera, Nairobi, Kenya. Habitat International, 60, 1-9. https://doi.org/10.1016/i.habitatint.2016.12.003 
Molina-Motos, D. (2019). Ecophilosophical principles for an ecocentric environmental education. Education Sciences, 9(1). https://doi.org/10.3390/educsci9010037

Mortreux, C., Safra de Campos, R., Adger, W. N., Ghosh, T., Das, S., Adams, H., \& Hazra, S. (2018). Political economy of planned relocation: A model of action and inaction in government responses. Global Environmental Change, 50, 123-132. https://doi.org/10.1016/i.gloenvcha.2018.03.008

NVivo. (2020). GMA - Nodes compared by number of coding references.

Pandebesie, E. S., Indrihastuti, I., Wilujeng, S. A., \& Warmadewanthi, I. (2019). Factors influencing community participation in the management of household electronic waste in West Surabaya , Indonesia.

Paragoso, G. P., Sapar, C. M. A., Magsayo, J. R., Lahoylahoy, M. E., Guarin, R. M. B., Paragoso, G. P., ... Guarin, R. M. B. (2018). Solid Waste Management in Linamon, Lanao Del Norte. 030034. https://doi.org/10.1063/1.5019525

Pargal, S., Huq, M., \& Gilligan, D. (1999). Social Capital in Solid Waste Management: Evidence from Dhaka, Bangladesh. (16).

Paul, J. G., Arce-jaque, J., Ravena, N., \& Villamor, S. P. (2018). Integration of the informal sector into municipal solid waste management in the Philippines - What does it need? Waste Management, 32(11), 2018-2028. https://doi.org/10.1016/j.wasman.2012.05.026

Perlaviciute, G., \& Squintani, L. (2020). Public Participation in Climate Policy Making: Toward Reconciling Public Preferences and Legal Frameworks. One Earth, 2(4), 341-348. https://doi.org/10.1016/i.oneear.2020.03.009

Permana, A. S., Towolioe, S., Aziz, N. A., \& Ho, C. S. (2015). Sustainable solid waste management practices and perceived cleanliness in a low income city. Habitat International, 49, 197205. https://doi.org/10.1016/i.habitatint.2015.05.028

Premakumara, D. G. J., Canete, A. M. L., Nagaishi, M., \& Kurniawan, T. A. (2014). Policy implementation of the Republic Act (RA) No. 9003 in the Philippines: A case study of Cebu $\begin{array}{llll}\text { city. Waste } & \text { 34(6), 971-979. }\end{array}$ https://doi.org/10.1016/j.wasman.2013.10.040

Purnomo, E. P., Ramdani, R., \& Tomaro, Q. P. V. (2019). Land ownership transformation before and after forest fires in Indonesian palm oil plantation areas. Journal of Land Use Science, 00(00), 1-15. https://doi.org/10.1080/1747423X.2019.1614686

Puspita, L., Kurnia, M. L., \& Yevendri. (2019). Law Enforcement Model in Community-Based Waste Monitoring and Management As a Realization of Good Environmental Governance Principles in West Sumatera, Indonesia. UNIFIKASI: Jurnal Ilmu Hukum, 6(1), 1. https://doi.org/10.25134/unifikasi.v6i1.1629

Putra, H. P., Damanhuri, E., \& Sembiring, E. (2019). Sektor Baru Pengelolaan Sampah di Indonesia (Studi Kasus di Kota Yogyakarta, Kabupaten Sleman dan Bantul). 11(November 2018), 11-24.

Raharjo, S., Matsumoto, T., Ihsan, T., \& Rachman, I. (2015). Community-based solid waste bank program for municipal solid waste management improvement in Indonesia : a case study 
of Padang city. Journal of Material Cycles and Waste Management. https://doi.org/10.1007/s10163-015-0401-z

Reflay, S. A., Hayu, I., \& Djumiarti, T. (2013). ANALISIS PERAN AKTOR IMPLEMENTASI DALAM KEBIJAKAN PENGELOLAAN SAMPAH DI KOTA SEMARANG UNIVERSITAS DIPONEGORO. In Journal of Public Policy and Management Review (Vol. 2).

Republik Indonesia. Undang-Undang Republik Indonesia Nomor 18 Tahun 2008 Tentang Pengelolaan Sampah. , (2008).

Riley, T. B., \& Sheridan, W. (2006). Comparing e-government vs. e-governance. (pp. 1-5). pp. 15. Commonwealth Center for e-Governance.

Roland, G. (2004). Understanding institutional change: Fast-moving and slow-moving institutions. Studies in Comparative International Development, 38(4), 109-131. https://doi.org/10.1007/BF02686330

Rosener, J. B. (1975). A cafeteria of techniques and critiques. Public Management, 57(12), 1619.

Rowe, G., \& Frewer, L. J. (2004). Evaluating public-participation exercises: A research agenda. Science Technology and Human Values, 29(4), 512-557. https://doi.org/10.1177/0162243903259197

Sembiring, E., \& Nitivattananon, V. (2010). Sustainable solid waste management toward an inclusive society: Integration of the informal sector. Resources, Conservation \& Recycling, 54(11), 802-809. https://doi.org/10.1016/j.resconrec.2009.12.010

Senate Economic Planning Office. (2017). Philippine Solid Wastes. Philippine Solid Wastes At A Glance, AG-17-01(01), 1-4.

Simeon, C. P. B., \& Aguja, H. J. (2017). Mandates And Wherewithals: The Research-Teaching Nexus In Gender Mainstreaming In The Msu-Iligan Institute Of Technology, Philippines. International Conference on Public Organization VII, 9-21.

Stein, S., \& Harper, T. (2000). The paradox of planning in a multicultural liberal society: a pragmatic reconciliation. Urban Planning in a Multicultural Society, 67-82.

Svallfors, $\quad$ S. $\quad$ (2010). Public $\quad$ Attitudes. https://doi.org/10.1093/oxfordhb/9780199579396.003.0016

Syam, D. M. (2014). Hubungan Pengetahuan dan Sikap Masyarakat Dengan Pengelolaan Sampah di Desa Loli Tasiburi Kecamatan Banawa Kabupaten Donggala. 21-26.

Syambudi, I. (2019). Warga Tutup Akses TPST Piyungan, Pemprov DIY Ajak Warga Negosiasi. Retrieved from https://tirto.id/warga-tutup-akses-tpst-piyungan-pemprov-diy-ajakwarga-negosiasi-dkjZ

the Republic of the Philippines. Ecological Solid Waste Management Act No. 9003 of 2000. , (2001).

Tinio, M. M. R., Rollon, A. P., \& Moya, T. B. (2019). Synergy in the urban solid waste management system in Malolos city, Philippines. Philippine Journal of Science, 148(1), 73-97. 
Tsai, T. (2008). The Impact of Social Capital on Regional Waste Recycling. 55(June 2007), 44-55.

Tufte, E. R. (1979). Political Parties, Social Class, and Economic Policy Preferences. Government and Opposition, 18-36.

Turner, M., \& Hulme, D. (1997). Governance, administration and development: Making the state work. Macmillan International Higher Education.

United Nations. (2019). World Population Prospects . Retrieved August 12, 2020, from Population Division website: https://population.un.org/wpp/

United Nations. (2020). The Sustainable Development Agenda. Retrieved May 8, 2020, from https://www.un.org/sustainabledevelopment/development-agenda/

Verba, S., \& Schlozman, K. L. (1977). Unemployment, Class Consciousness, and Radical Politics: What Didn't Happen in the Thirties. The Journal of Politics, 39(2), 291-323. https://doi.org/10.2307/2130053

Wahab, S. (2015). Impact of social capital on community-based urban solid waste management initiative in Ibadan, Nigeria. The Journal of Solid Waste Technology and Management, 41(4), 341-356.

Wahyudi, A., Abdillah, R. A., \& Nutqhi, A. I. I. (2012). Strategi Dinas Lingkungan Hidup Kota Malang Dalam Mengatasi Permasalahan Sampah di Era Revolusi Industri 4.0. Prosiding Simposium Nasional, 1018-1045.

Wilson, D. C. (2007). Development drivers for waste management. Waste Management \& Research, 25(3), 198-207. https://doi.org/10.1177/0734242X07079149

Worcester, R. M. (1993). Public And Élite Attitudes To Environmental Issues. International Journal of Public Opinion Research, 5(4), 315-334. https://doi.org/10.1093/ijpor/5.4.315

Wynne, A. L., Nieves, P. M., Vulava, V. M., Qirko, H. N., \& Callahan, T. J. (2018). A communitybased approach to solid waste management for riverine and coastal resource sustainability in the Philippines. Ocean \& Coastal Management, 151, 36-44. https://doi.org/10.1016/i.ocecoaman.2017.10.028

Yang, K., \& Pandey, S. K. (2011). Further Dissecting the Black Box of Citizen Participation: When Does Citizen Involvement Lead to Good Outcomes? Public Administration Review, 71(6), 880-892. https://doi.org/10.1111/j.1540-6210.2011.02417.x

Yogiswatin, G. (2014). Studi Komparasi Perilaku Masyarakat Dalam Pengelolaan Sampah Rumah Tangga di Desa Babakan dan Desa Ciwaringin Kecamatan Ciwaringin Kabupaten Cirebon. $1-14$

Zarate, M. A., Slotnick, J., \& Ramos, M. (2008). Capacity building in rural Guatemala by implementing a solid waste management program. Waste Management, 28(12), 25422551. https://doi.org/10.1016/j.wasman.2007.10.016

Zhang, G., Deng, N., Mou, H., Zhang, Z. G., \& Chen, X. (2019). The impact of the policy and behavior of public participation on environmental governance performance: Empirical analysis based on provincial panel data in China. Energy Policy, 129(222), 1347-1354. https://doi.org/10.1016/j.enpol.2019.03.030 
Zin, R. H. M., Lee, H. A., \& Rahman, S. A. (2002). Social Protection in Southeast and East Asia Towards a Comprehensive Picture (Vol. 53). https://doi.org/10.1111/1468-2451.00343 